\title{
On using ethnonyms in the cooperative situation of interethnic interaction
}

\author{
N. I. Liutianska \\ Petro Mohyla Black Sea National University, Mykolaiv, Ukraine \\ Natalia Liutianska. E-Mail: natalka.lyutyanska@gmail.com \\ Paper received 25.05.18; Accepted for publication 03.06.18.
}

\section{https://doi.org/10.31174/SEND-Ph2018-166VI49-05}

\begin{abstract}
The present paper deals with the notion of ethnonyms and their usage in the cooperative situation of interethnic interaction. The latter are studied on the basis of British and American media discourse, which spreads information about life in ethnically heterogeneous countries. Typology of the ethnonyms used in British and American media is given in the present paper. Moreover, vivid examples of different types of ethnonyms are considered.
\end{abstract}

Keywords: media discourse, ethnonym, cooperative situation, interethnic interaction, reference.

Introduction. The human interaction in the modern world takes place between representatives of different ethnic and cultural groups. Hence, the notion of situation of interethnic interaction arises. When communicative aim is achieved one can say about cooperative interaction. The latter can be spread via different forms and media discourse is one of them.

Modern media contain names of nation representatives that are participants of interethnic interaction situations. Native speakers, the English language in particular, describe representatives of other nations with the help of ethnonyms.

Ethnonyms of the modern English language are subdivided into official and figurative ones. The official ethnonyms are proper names or popular personal names of a nation representative, while the latter refer to appearance, racial identity, cultural peculiarities, such as lifestyle, typical behavior and food preferences, e.g.

spaghetti bender, moustache Pete - for Italians, frogs for the French [2, p. 103].

It should be mentioned that the word "ethnonym" originates from the Greek éthnos or "people" and ónoma or "name", it is one-word non-discriptory name referring to people on the national or state basis, e.g. American, Chinese, Maltese [1, p. 8]. Ethnonyms are based not only on the basis of a national origin, but also on the place of living. Such definition describes modern ethnic situation when representatives of different ethnic groups live on the territory of one state.

There is one more definition of this notion. It defines nominative unit with neutral or even positive attitude towards certain ethnic group, e.g. Brazilian, Canadian, Estonian [3, p. 22]. The opposite group of ethnonyms should be considered which has the name "ethnophobisms". They are defined as onomastic units used to nominate certain ethnic groups. Furthermore, these units are used to offend representatives of out-groups, e.g. Chink, Chinky referring to the Chinese [3, p. 22].

Ethnonyms are different from linguonyms or language names, e.g. English, German, Finnish [5, p. 8]. Ethnonyms and linguonyms are separate notions. They can coincide, but not necessarily.

Ethnonyms and ethnophobisms are used for evaluation of representatives of out- and in-groups. They are certain ethnic images [4, p. 83]. E.g. African Americans who succeed are called firsts, fat cat, people from the East little people, ricer. Ethnonyms apple (red on the outside, white inside), Uncle Tomahawk are widely used among Native Americans.

It should be mentioned that ethnonyms can often provoke ethnic bias.

Methods and corpus. The present research was conducted on the material of British and American media which spread information in multicultural Great Britain and the United States of America. A series of articles taken from those media was studied. It should be mentioned that articles were chosen from both tabloids and qualitative press.

The critical discourse analysis is the main method used while carrying out this research. The above mentioned term is used to denote the critical linguistic approach of scholars finding the larger discursive unit of text to be the basic unit of communication $[6$, p. 6]

Results and discussion. The findings of this research show that ethnonyms of cooperative situation of interethnic interaction in the British media are divided into official and figurative ones. Furthermore, official ethnonyms refer to national origin of participants of communication and place of living. It should be mentioned that figurative ethnonyms apart from place of living of individuals in the British media refer to their religion [see Table 1].

Table 1. Types of ethnonyms of cooperative interethnic interaction situation (British media)

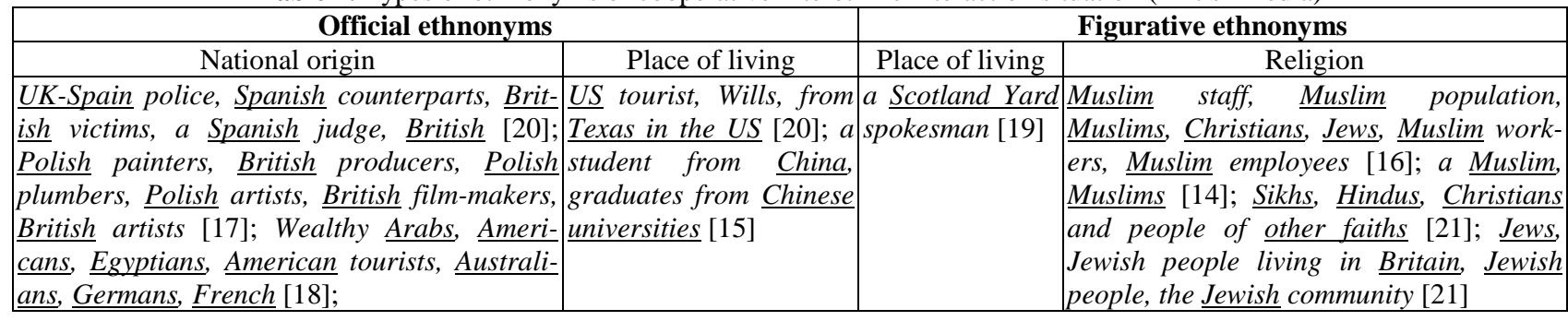


Ethnonyms in the British media discourse designate participants of cooperative communication. Moreover, they show their cultural and ethnic identity.

Ethnonyms of the British media are additional means of creating ethnic images.

The findings of this research also indicate that ethnonyms of cooperative situation in the American media dis- course are also represented by official and figurative ethnonyms. The former are subdivided on the basis of national origin and place of living of individuals. Whereas figurative ethnonyms indicate place of living, religion and ethnic and racial identity of communication participants [see Table 2].

Table 2. Types of ethnonyms of cooperative interethnic interaction situation (American media)

\begin{tabular}{|c|c|c|c|c|}
\hline \multicolumn{2}{|c|}{ Official ethnonyms } & \multicolumn{3}{|c|}{ Figurative ethnonyms } \\
\hline National origin & Place of living & Place of living & Religion & Ethnic and racial identity \\
\hline $\begin{array}{l}\text { US airmen, } \frac{\text { Chinese sailors }}{[13] ; \text { British man, British of }} \\
\text { ficers } \\
{[11] ; \text { American citizens }} \\
{[11]}\end{array}$ & $\begin{array}{l}\text { Chicago's Nepalese community, } \\
\text { Chicagoans from Nepal, Local Ne- } \\
\text { pali community, the Nepali commu- } \\
\text { nity in Chicago [8] }\end{array}$ & 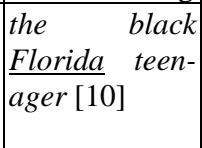 & A $\begin{array}{l}\text { Muslim } \\
\text { woman }\end{array}$ & $\begin{array}{l}\text { Hispanics [11]; Minority stu- } \\
\text { dents, white enrollment, } \underline{\text { white }} \\
\text { majority, black, black student } \\
\text { population, white students [9] }\end{array}$ \\
\hline
\end{tabular}

Ethnonyms of American media create ethnic images of the communication participants. Moreover, ethnonyms apart from nominating representatives of in- and outgroups, help to create positive image for American society. At the same time ethnonyms are the factors of emerging ethnic and racial prejudice.

Therefore, ethnonyms of both British and American media are the linguistic units that create native speaker's images of in- and out-groups. Such images form characteristic features for some ethnic groups. That is why the system of ethnonyms is represented by official ethnonyms used for describing national origin and place of living of communication participants. Figurative ethnonyms indicate racial and religious identity of the participants.

\section{REFERENCES}

1. Ковалев Г.Ф. Этнос и имя: цикл ст. / Г.Ф. Ковалев. - Воронеж: Воронеж. гос. ун-т, 2006. - 235 с.

2. Коцур М.Ф. Этнонимические названия образного характера в современном английском языке [Электронный ресурс]. http://dspace.nbuv.gov.ua/bitstream/handle/123456789/15096 125-Kocur.pdf?sequence $=1$

3. Левицький А.Е. Етнономінації у дзеркалі міжкультурної комунікації / А.Е. Левицький, Ю.В. Святюк. - К. : Логос, 2010. - $134 \mathrm{c}$

4. Сорокин Ю.А. Какими себя видят русские и американцы? / Ю.А. Сорокин // Когнитивная лингвистика конца XX века. Материалы Международной научной конференции. 7-9 октября 1997 г. в трех частях. - Ч.1. - Минск : Изд-во МГЛУ. - С. 81-85.

5. Шен Д.А. Этноним в лексико-семантическом пространстве английского языка: автореф. дисс. на соискание науч. степени канд. филол. наук: спец. 10.02.04 «Германские языки» / Дарья Александровна Шен. - Нижний Новгород, 2009. $-22 \mathrm{c}$.

6. Wodak, R., Meyer, M. Methods of Critical Discourse Analysis. - London: Sage, 2001. - 200 p.

7. British man arrested in Christmas Day hack attack on Sony, Xbox, by Bloomberg [Electronic resource] // The Los Angeles Times. - 18 January 2015. - Mode of access: http://touch.latimes.com/\#section/617/article/p2p-82552963/

8. Chicago's Nepalese community begins fundraising efforts [Electronic resource] // The Chicago Tribune. - 27 April 2015. - Mode of access: http://my.chicagotribune.com/\#section/590/article/p2p83393311/

9. Minority students make up new majority in Illinois public schools [Electronic resource] //The Chicago Tribune. - 6 January 2014. - Mode of access: http://articles.chicagotribune.com/2014-01-06/news/ctmajority-minority-schools-20140106_1_minority-studentspublic-school-students-black-and-latino-students

10. Obama announces initiative for young black and Latino men [Electronic resource] // The Los Angeles Times. - 28 February 2014. - 2 Mode of access: http://www.latimes.com/nation/la-na-obama-race-initiative20140228,0,6238654.story\#ixzz2udNJKiTb
11. Obama hopes to score points in Miami on immigration [Electronic resource] // The New York Times. - 25 February 2015. - Mode of access: http://www.nytimes.com/2015/02/26/us/politics/obamahopes-to-score-points-in-miami-onimmigra-

tion.html hp\&action $=$ click\&pgtype $=$ Homepage $\&$ module $=$ fir st-column-region\&region=top-news\&WT.nav=topnews\&_r=0

12. Supreme Court seems to side with Muslim woman in discrimination case [Electronic resource] // The Washington Post. - 25 February 2015. - Mode of access: http://www.washingtonpost.com/politics/courts_law/supreme -court-seems-to-side-with-muslim-woman-in-discriminationcase/2015/02/25/debea670-bcf8-11e4-bdfab8e8f594e6ee_story.html?hpid=z3

13. US airmen parachute in to help Chinese sailors [Electronic resource] // The Boston Globe. - 4 May 2014. - Mode of access:

http://www.bostonglobe.com/news/nation/2014/05/04/teamaids-injured-chinese-sailors-

pacific/cfhKEFEehOGfExib0FuadN/story.html

14. Burqa wearers banned from Australian parliament's open public galleries [Electronic resource] // The Guardian. - 2 October 2014. - Mode of access: http://www.theguardian.com/australianews/2014/oct/02/new-rules-ban-burqa-wearers-fromparliaments-open-public-galleries

15. 'Chinese students think British boys are gentlemen, but when they get drunk they go crazy' [Electronic resource] //The Guardian. - 20 October 2014. - Mode of access: http://www.theguardian.com/education/2014/oct/20/-sp-meeta-student-from-china

16. M\&S tells Muslim staff they CAN refuse to serve customers bying alcohol or pork [Electronic resource] // The Daily Mail. - 22 December 2013. - Mode of access: http://www.dailymail.co.uk/news/article-2527820/MarksSpencer-tells-Muslim-staff-CAN-refuse-serve-customersbuying-alcohol-pork.html

17. Polish painters called in to get UK Van Gogh film job done [Electronic resource] // The Guardian. - 18 March 2014. Mode

of

access: 
http://www.theguardian.com/film/2014/mar/18/uk-van-goghfilm-polish-artists

18. Spend, spend, spend! How wealthy Arabs lavish $£ 4.5$ million a DAY in UK, cementing London's status as global playground of rich [Electronic resource] // The Daily Mail. - 27 May 2014. - Mode of access: http://www.dailymail.co.uk/news/article-2636238/Spendspend-spend-How-wealthy-Arabs-lavish-4-5-million-DAYUK-cementing-Londons-status-global-playgroundrich.html\#ixzz32vwMg09A

19. UK-Spain police swoop on shares fraud leads to 110 arrests [Electronic resource] // The Guardian. - 28 February 2014. -
Mode of access: http://www.theguardian.com/uknews/2014/feb/28/swoop-on-boiler-room-110-arrests

20. US tourist locked inside London bookshop [Electronic resource] // The Guardian. - 17 October 2014. - Mode of access: http://www.theguardian.com/uk-news/2014/oct/17/ustourist-locked-inside-london-waterstones-book-shop

21. 'Without its Jews, Britain would not be Britain', warns Theresa May over fears of an exodus in wake of anti-Semitic attacks [Electronic resource] // The Daily Mail. - 18 January $2015 . \quad-\quad$ Mode of access: http://www.dailymail.co.uk/news/article-2915480/WithoutJews-Britain-not-Britain-warns-Theresa-fears-exodus-wakeanti-Semitic-attacks.html

\section{REFERENCES}

1. Kovalev H.F. Ethnic group and name: series of articles. Voronezh: Voronezh State University, 2006. - 235 s.

2. Kotsur M.F. Figurative ethnonyms in the modern English language [Electronic resource]. - Mode of access: http://dspace.nbuv.gov.ua/bitstream/handle/123456789/15096 125-Kocur.pdf?sequence $=1$

3. Levytskyi A.E., Svyatyuk Yu.V. Ethnonyms in the intercultural communication: a monograph. - K.: Logos, 2010. - 134 s.

4. Sorokin Yu.A. How do Russians and Americans see themselves? // Cognitive linguistics of the end of XX century. Proceedings of International Scientific Conference. 7-9 October1997 in 3 parts. - Part 1. - Minsk: MGLU Publishing House. - S. 81-85.

5. Shen D.A. Ethnonym in lexical and semantic field of the English language: dissertation abstract in the fulfilment of requirements for the degree of candidate of philological sciences: 10.02.04 "Germanic Languages"/ Daria Aleksandrovna Shen. - Nizhniy Novgorod, 2009. - 22 s.

\section{Использование этнономинаций в кооперативной ситуации межэтнического взаимодействия}

Н. И. Лютянская

Аннотация. Статья посвящена изучению этнономинаций в кооперативной ситуации межэтнического взаимодействия. Вышеупомянутое понятие исследовано на материале британского и американского масс-медийного дискурса, которые вербализируют информацию о жизни в этнически неоднородных странах, таких как Великобритания и Соединенные Штаты Америки. Также в статье представлена типология этнономинаций, использованных в британских и американских массмедиа. Кроме того, представлены яркие примеры различных типов этнономинаций.

Ключевые слова: масс-медийный дискурс, этнономинации, кооперативная ситуация, межэтническое взаимодействие, номинация 